\title{
mTOR inhibition with rapamycin mitigates radiation-induced pulmonary fibrosis in a murine model
}

\author{
Eun Joo Chung, $\mathrm{PhD}^{1}$, Anastasia Sowers, $\mathrm{BS}^{2}$, Angela Thetford, $\mathrm{BS}^{2}$, Grace McKay- \\ Corkum, BA ${ }^{1}$, Su I. Chung, PhD ${ }^{1}$, James B. Mitchell, PhD ${ }^{2}$, and Deborah E. Citrin, MD ${ }^{1}$ \\ ${ }^{1}$ Radiation Oncology, Center for Cancer Research, National Institutes of Health, Bethesda, \\ Maryland ${ }^{2}$ Radiation Biology Branches, Center for Cancer Research, National Institutes of Health, \\ Bethesda, Maryland
}

\begin{abstract}
Background-Radiation-induced pulmonary fibrosis (RIPF) is a late toxicity of therapeutic radiation. mTOR signaling drives several processes implicated in RIPF, including inflammatory cytokine production, fibroblast proliferation, and epithelial senescence. We sought to determine if mTOR inhibition with rapamycin would mitigate RIPF.
\end{abstract}

Methods/Materials-C57BL/6NCr mice received a diet formulated with rapamycin (14 mg/kg food) or control diet two days before and continuing for 16 weeks after exposure to 5 daily fractions of 6 Gy thoracic irradiation (IR). Fibrosis was assessed with Masson-Trichrome staining and hydroxyproline assay. Cytokine expression was evaluated by quantitative real time PCR. Senescence was assessed by staining for beta-galactosidase activity.

Results-Administration of rapamycin extended the median survival of irradiated mice compared to control diet from 116 days to 156 days $(\log$ rank $\mathrm{p}=0.006)$. Treatment with rapamycin reduced hydroxyproline content compared to control diet (IR+vehicle: $45.9 \pm 11.8$, IR+rapamycin: $21.4 \pm 6.0, \mathrm{p}=0.001)$ and reduced visible fibrotic foci. Rapamycin treatment attenuated IL- $1 \beta$ and TGF- $\beta$ induction in irradiated lung compared to control diet. Type II pneumocyte senescence after IR was reduced with rapamycin treatment at 16 weeks (three-fold reduction at 16 weeks, $\mathrm{p}<0.001)$.

Conclusion-Rapamycin protected against RIPF in a murine model. Rapamycin treatment reduced inflammatory cytokine expression, extra cellular matrix production, and senescence in type II pneumocytes.

*Corresponding Author: Deborah Citrin, M.D., Radiation Oncology Branch, National Cancer Institute, Building 10 CRC, B2-3500, Bethesda, MD, Telephone: 301-496-5457, Fax: 301-480-5439, citrind@ mail.nih.gov.

Publisher's Disclaimer: This is a PDF file of an unedited manuscript that has been accepted for publication. As a service to our customers we are providing this early version of the manuscript. The manuscript will undergo copyediting, typesetting, and review of the resulting proof before it is published in its final citable form. Please note that during the production process errors may be discovered which could affect the content, and all legal disclaimers that apply to the journal pertain.

Conflicts of Interest: The authors declare that they have no conflicts of interest to disclose 


\section{Keywords}

Radiation; Fibrosis; Rapamycin; mTOR

\section{BACKGROUND}

Irradiation of normal lung is an unfortunate consequence of radiotherapy for thoracic malignancies. Lung is particularly sensitive to radiation injury which may result in substantial morbidity and mortality. The risk of radiation pneumonitis and fibrosis frequently limit radiation treatment fields and dose. Unfortunately, few effective therapies for radiationinduced pulmonary fibrosis (RIPF) exist.

The alveolar epithelium is comprised of two types of pneumocytes (airway epithelial cell, AEC). AECII are less common than AECI, but function as the alveolar stem cell, proliferating in response to injury and differentiating into both AECI and AECII (1). Targeted depletion of AECII is sufficient to induce fibrosis (2), highlighting the importance of AECII in lung homeostasis. Recently, a time- and dose-dependent increase of AECII senescence and pneumocyte depletion after exposure to fibrosis-inducing doses of irradiation (IR) was reported (3). Irradiated, senescent AECII were capable of stimulating fibroblast proliferation and collagen secretion. These findings suggested that AECII senescence plays a role in RIPF and identified a novel target for intervention.

The mammalian target of rapamycin (mTOR) plays a central role in the regulation of cell growth and cancer progression (4). Pharmacologic inhibition of mTOR signaling has shown promising anti-cancer activity in experimental models and clinical trials (5). Paradoxically, mTOR inhibition elongates lifespan and delays cancer and age related diseases $(6,7)$.

Although many mechanisms may contribute to these effects, rapamycin is thought to prevent senescence in response to damaging stimuli $(8,9)$ and to inhibit the production of the proinflammatory senescence associated secretory phenotype (SASP) (10).

We hypothesized that mTOR inhibition with oral delivery of rapamycin would reduce AECII senescence after IR and ameliorate RIPF. Mice treated with rapamycin after thoracic irradiation demonstrated reduced mortality and collagen accumulation compared to irradiated mice that did not receive rapamycin. Further, rapamycin treatment reduced AECII senescence and cytokine elaboration in irradiated lungs.

\section{METHODS AND MATERIALS}

\section{Animal models}

Animal studies were institutionally approved and deemed in accordance with the guidelines of the Institute of Laboratory Animal Resources, National Research Council. Rapamycin (LC Laboratories, Woburn, MA) was prepared as previously described (11) to deliver 14 $\mathrm{mg} / \mathrm{kg} /$ day beginning two days prior to radiation and continuing for 16 weeks. Ten week old female C57BL/6NCr mice were restrained in a custom Lucite jig with lead shielding that allowed for selective irradiation of the thorax. Five daily fractions of $6 \mathrm{~Gy}$ were delivered with a XRAD320 X-ray irradiator (Precision X-ray, Inc., North Branford, CT) using $2.0 \mathrm{~mm}$ 
Al filtration ( $300 \mathrm{kV}$ peak) at a dose of $2.3 \mathrm{~Gy} / \mathrm{min}$. All mice were allowed ad libitum access to food and water.

Mice were followed for survival $(n=8)$ or tissue collection $(n \geq 3$ per condition and time point). Lung tissue was snap frozen for biochemical assays or inflated with neutral buffered formalin or OCT for histology.

\section{Histopathology and histochemistry}

Deparafffinized lung sections were incubated in Bouin's picric-formalin and stained using Masson's trichrome with aniline blue as the collagen stain and Weigert's iron hematoxylin as the nuclear counterstain. Digital micrographs were captured at $40 \times$ magnification and imported into QCapture (Quantitative Imaging Corporation, Surrey, BC, Canada).

For immunohistochemical staining, heat and pressure based antigen retrieval was performed in citrate buffer, pH 6.0 (Electron Microscopy Sciences, Hatfield, PA). Endogenous peroxidase activity was quenched with $0.3 \% \mathrm{H}_{2} \mathrm{O}_{2}$ in water for 5 minutes. Sections blocked in $2.5 \%$ normal horse serum were incubated in diluted primary antibody followed by a peroxidase conjugated secondary antibody. Following incubation with Impact 3,3'diaminobenzidine (Vector Laboratories, Burlingame, CA), sections were washed and counterstained with hematoxylin (Sigma Aldrich, St Louis, MO).

The $\beta$-galactosidase ( $\beta$-Gal) activity assay (Abcam, Cambridge, MA) was performed according to the manufacturer's instructions in frozen lung sections or primary pneumocytes. For co-staining, sections were then incubated with an anti-prosurfactant-C antibody (Abcam, Cambridge, MA), a marker of AECII, and a compatible secondary antibody conjugated to Alexa Fluor 594 (Life technologies, Grand Island, NY).

\section{Hydroxyproline Assay}

The right lung ( $\mathrm{n}=3$ mice per cohort) was weighed and mechanically homogenized. Lung tissue was hydrolyzed in $1 \mathrm{ml}$ of $6 \mathrm{~N} \mathrm{HCl}$ at $110^{\circ} \mathrm{C}$ for 18 hours. Hydrolysate was analyzed with the Biovision Hydroxyproline assay kit (Milpitas, CA). Pulmonary hydroxyproline per mouse was calculated based upon total lung weight.

\section{Enrichment of primary pneumocytes}

Primary pneumocytes were isolated from C57BL/6NCr mice as described previously (3) and as detailed in the supplemental methods.

\section{Western Blotting}

Lung tissue extracts were prepared using radioimmunoprecipitation assay buffer (RIPA buffer, Pierce) containing protease inhibitors (Roche Applied Science) and phosphatase inhibitors (Sigma-Aldrich). Isolated proteins were subjected to western blot analysis. Primary antibodies are detailed in the supplemental methods. Primary antibodies against each protein were detected by secondary antibodies conjugated with horseradish peroxidase (Santa Cruz Biotechnology, Inc., Dallas, TX). Specific bands for each protein were detected by ImageQuant LAS4000 (GE Healthcare Life Science, Pittsburgh, PA) using the 
SuperSignal Chemiluminescence kit (Thermo Scientific, Rockford, IL). Densitometric analysis was performed using ImageJ software (NIH, Bethesda, MD) with the expression of each molecule normalized to actin.

\section{Real-time Quantitative RT-PCR}

Total RNA was extracted using the RNeasy plus mini kit (Qiagen, Valencia, CA). After genomic DNA elimination with DNA eliminator columns, $1 \mu \mathrm{g}$ of total RNA was reverse transcribed into first-strand cDNA using a QuantiTect Reverse Transcription kit (Qiagen). Cytokine expression was analyzed with quantitative real-time PCR using TaqMan ${ }^{\circledR}$ Gene Expression assay primers and reagents (Applied Biosystems, Foster City, CA) with $0.5 \mu \mathrm{g}$ of cDNA assayed in a $20 \mu \mathrm{L}$ reaction volume. The reactions were incubated for 2 minutes at $50{ }^{\circ} \mathrm{C}$, for 10 minutes at $95^{\circ} \mathrm{C}$ for initial denaturing and followed by 50 cycles of $95^{\circ} \mathrm{C}$ for 15 seconds and $60^{\circ} \mathrm{C}$ for 1 minute in 7500 real-time PCR system (Applied Biosystems, Foster City, CA). The expression of each cytokine (TGF- $\beta$, IL-1 $\beta$, IL- 6 and TNF- $\alpha$ ) was normalized to the endogenous control (HPRT-1).

\section{Statistical Analysis}

Comparisons between conditions were conducted with ANOVA (Kruskal-Wallis test with Dunn's post-test). A p value of less than 0.05 was considered statistically significant. In vitro studies were performed in duplicate and validated in three separate experiments. For immunohistochemistry, cell counts were conducted in five randomly selected high power fields (40x) in each lung (15 fields per group).

\section{RESULTS}

\section{Rapamycin inhibits irradiation induced activation of mTOR signaling}

To verify that mTOR activation occurred as a result of irradiation in our model, and to confirm that oral delivery of rapamycin was capable of inhibiting downstream signaling mediators associated with senescence (12), the expression and phosphorylation of S6K, 4EBP1 and S6 were measured in lung tissue collected at 16 weeks after irradiation by western blotting (Figure 1A). Phosphorylation of the downstream mediators S6 and S6K was observed in response to irradiation in control diet-fed mice, but was reduced after rapamycin treatment (Figure 1A).Immunofluorescence confirmed that radiation-induced S6 phosphorylation in lung tissue was markedly reduced after rapamycin treatment compared to control diet (Figure 1B). A similar pattern of target phosphorylation was seen at week 2 (Supplemental Figure 1).

\section{Rapamycin extends time to mortality after lethal thoracic irradiation}

Fractionated thoracic irradiation ( $5 \times 6 \mathrm{~Gy}$ ) resulted in rapid pulmonary death (Figure $2 \mathrm{~A}$ ). Kaplan-Meier analysis demonstrated a significant improvement in median survival of irradiated mice with rapamycin treatment compared to that in mice treated with the control $\operatorname{diet}(22.3$ versus 16.6 weeks, $\mathrm{p}<0.001)$. Moribund mice in both groups exhibited rapid respiration and weight loss with evidence of pulmonary edema at necropsy, consistent with a pulmonary cause of death. One mouse from each radiation treatment group was euthanized for severe dermatitis without evidence of lung toxicity (censored from analysis). 


\section{Rapamycin reduces fibrosis in irradiated lung}

To compare the extent of RIPF between treatment groups, lung tissue collected at 16 weeks after irradiation was analyzed. Hydroxyproline content of the irradiated lungs of control diet-fed mice was significantly higher than that observed in lung tissue from unirradiated mice ( $44.7 \pm 11.1$ vs. $25.6 \pm 4.9 \mu \mathrm{g}$ per lung, $\mathrm{p}=0.0014)$ and that observed in rapamycin dietfed, irradiated mice ( $44.7 \pm 11.1$ vs. $21.4 \pm 6.0 \mu \mathrm{g}$ per lung, $\mathrm{p}=0.0001)$ (Figure $2 \mathrm{~B}$ ).

Similarly, Masson-trichrome staining of lung tissue revealed extensive collagen accumulation in the lungs of control-fed, irradiated mice, but not in that of rapamycin-fed, irradiated mice. Collagen accumulation in both groups was noted throughout the lung but was observed to the greatest degree in the sub-pleural region (Figure 2C, Supplemental Figure 2).

\section{Effects of rapamycin on radiation induced cytokine expression in murine lungs}

Pro-inflammatory cytokines, such as IL-6, IL-1 $\beta$, and TNF- $\alpha$, and the pro-fibrotic cytokine, TGF- $\beta$, are known to play a critical role in radiation induced fibrosis $(13,14)$ and in senescence-associated signaling $(15,16)$. The effects of rapamycin on radiation-induced cytokine expression in lung was assessed with real-time PCR. The expression of TGF- $\beta$, IL-1 $\beta$, IL-6, and TNF- $\alpha$ were increased in irradiated lung tissue compared to unirradiated lung tissue (Figure 3 ). The expression of IL-1 $\beta$ and TGF- $\beta$ were significantly reduced in the irradiated lungs of mice treated with rapamycin compared to controls, whereas the expression of TNF- $a$ and IL-6 were minimally changed with rapamycin treatment.

\section{Rapamycin inhibits macrophage accumulation}

Inflammatory cell infiltration in irradiated lung tissue is known to contribute to radiation lung injury (17) and rapamycin has known immunomodulatory effects (18). To determine if rapamycin treatment altered the accumulation of immune cells after irradiation, immunohistochemical detection of neutrophils, macrophages, and T-cells was performed in lungs tissue sections. Thoracic irradiation resulted in a significant accumulation of neutrophils, T-cells, and macrophages after irradiation (Figure 4). Treatment with rapamycin significantly reduced macrophage accumulation after irradiation ( $3.4 \pm 1.5$ vs. $22.9 \pm 8.6$ macrophages per high power field, $\mathrm{p}=0.0003$ ), but did not significantly alter neutrophil and T-cell accumulation.

\section{Rapamycin prevents radiation-induced AECII senescence}

To determine if rapamycin was capable of reducing pneumocyte senescence after irradiation, SA $\beta$-Gal expression was evaluated in lung tissue and in primary pneumocyte cultures. An increase in senescent AECII was observed after irradiation, with the highest levels observed 16 weeks compared to earlier time points (Figure 5). Treatment with rapamycin after irradiation reduced AECII senescence at all time points compared to irradiation with control diet. To confirm that rapamycin was capable of directly inhibiting pneumocyte senescence without the confounding effects of immune cells, primary pneumocyte cultures were treated with rapamycin in the presence or absence of radiation (Figure 5C). A significant reduction in the proportion of AECII that were senescent after irradiation was observed with rapamycin treatment compared to vehicle treatment ( $34.7 \%$ vs. $8.3 \%, \mathrm{p}=0.02)$. The number 
of AECII per alveolus was significantly higher after rapamycin treatment compared to control diet treatment, however both radiated groups had significantly less AECII per alveolus than unirradiated controls (Figure 5D).

\section{DISCUSSION}

The present study demonstrates that delivery of rapamycin reduces RIPF and significantly prolongs survival after lethal thoracic irradiation in C57BL/6NCr mice. Treatment with rapamycin resulted in inhibition of radiation induced signaling downstream of mTOR and reduced expression of pro-fibrotic, pro-inflammatory, and senescence associated cytokines in irradiated lungs. Further, the lung tissue of mice treated with rapamycin exhibited a marked reduction in macrophage accumulation, collagen content, and AECII senescence. The ability of rapamycin to inhibit RIPF and AECII senescence is novel. Collectively, these data suggest that targeting mTOR signaling may provide a therapeutic option in the setting of radiation-induced lung injury.

The mTOR signaling pathway is known to play an essential role in aging and senescence. mTOR is a serine/threonine protein kinase existing in two complexes, mTORC1 or mTORC2, consisting of distinct sets of protein-binding partners (19-21). mTORC1 signaling is rapamycin sensitive and is thought to mediate the effects of the pathways on aging and senescence through p70S6 kinase (p70S6K)/S6 kinase 1 (S6K1) $(22,23)$. We observed an increase in phosphorylation of this senescence associated signaling target after irradiation, consistent with activation of mTORC1 signaling in our model. Treatment with rapamycin significantly reduced S6 phosphorylation after irradiation, confirming that the oral delivery employed for this study was capable of inhibiting pro-senescence signaling via mTOR. The phosphorylation of 4EBP1 was not reduced in irradiated lung with rapamycin treatment at 16 weeks after irradiation, consistent with prior reports that $\mathrm{S} 6 \mathrm{~K}$ phosphorylation is permanently inhibited by rapamycin whereas 4EBP1 is rephosphorylated after prolonged rapamycin treatment (24-26).

At the cellular level, rapamycin has been shown to suppress senescence induced by cellular stress (27) as well as oncogene induced senescence and replicative senescence $(28,29)$. Inhibition of radiation induced senescence with rapamycin has been demonstrated in salivary stem cells (8), endothelial cells (30), and hematopoietic stem cells (31). Senescence of AECII, the alveolar stem cell, has previously been demonstrated after irradiation, and has been correlated with pneumocyte depletion (3), suggesting an association of AECII senescence with RIPF. These findings coupled with the known role of mTOR signaling in radiation-induced senescence supported mTOR inhibition as a method to prevent radiation lung injury. Although the current study again draws an association between inhibiting AECII senescence and prevention of radiation induced lung injury, a direct causative link of senescence and RIPF fibrosis cannot be implied.

Senescence of AECII is hypothesized to result in pneumocyte depletion. Additionally, senescent AECII may elaborate pro-inflammatory and pro-fibrotic molecules, several of which have been implicated in RIPF. We chose to examine the effects of rapamycin on four cytokines because of their known role in both radiation injury and senescence. TGF- $\beta$, 
IL-1 $\beta$, and IL-6 are recognized as drivers of radiation-induced fibrosis (32-35) and are known components of the SASP (36). Similarly, TNF-a signaling has been demonstrated as an important contributor to radiation lung injury (37), and several TNF-a related molecules are components of the SASP, such as sTNFR1, TRAIL-R3, Fas, sTNFRII (36).

In our model, rapamycin was capable of reducing TGF- $\beta$ and IL- $1 \beta$ expression in irradiated lung tissue, suggesting repression of these central fibrosis associated cytokines. Many cell types contribute to the expression of TGF- $\beta$ in irradiated lung, including pneumocytes, fibroblasts, and macrophages (32). Indeed, treatment with rapamycin was associated with a reduction in macrophage infiltration after irradiation, consistent with the known role of mTOR in immune modulation (18). Regardless of the source, the reduction in TGF- $\beta$ expression is consistent with the observed decrease in fibrosis. Similarly, the IL-1 family of cytokines has a critical role in sterile inflammation provoked by cellular damage, with IL-1 $\beta$ implicated in macrophage recruitment and retention (38). Thus, the reduction in macrophage infiltration in irradiated lung after rapamycin treatment is consistent with a reduction in IL-1 $\beta$ expression.

There was no effect of rapamycin treatment on the expression of IL-6 and TNF-a, both of which were increased after irradiation in lung tissue. The lack of difference after treatment with rapamycin in the setting of markedly reduced senescence suggests that senescent AECII are not the major source of these cytokines in irradiated lung. Indeed, a number of cell types are also capable of elaboration of these cytokines $(39,40)$. Further, the marked reduction of fibrosis in the context of continued enhanced expression of IL-6 and TNF-a after irradiation and rapamycin treatment are consistent with a secondary role of these cytokines in our model.

The use of rapamycin in this model provides a rationale for the further evaluation of the importance of mTOR signaling in RIPF. Although the use of mTOR inhibitors in this context is exciting due to its availability for clinical trials and evidence suggesting tumor radiosensitization with mTOR inhibition (41-46), this must be tempered by the previously observed toxicities of mTOR inhibitors (18). One adverse event in particular, reversible pneumonitis, is of obvious concern, but appears to be dosing sensitive and completely reversible with treatment cessation (47). Optimization of dosing has been effective in minimizing this toxicity, allowing successful use of these agents in the treatment of lung pathologies (48). The doses of rapamycin employed in this study are consistent with those used in animal aging studies, in which low-dose long term dosing is utilized and favored over the higher dosing utilized in tumor and radiosensitization studies (49).

Recently, mTORC1/2 inhibitors have been developed to allow more complete inhibition of mTORC1 and to inhibit mTORC2, which is not inhibited by rapamycin (50). These agents have also been shown to have radiation dose modifying activity $(51,52)$. Further, mTORC2 inhibitors are also of interest in the setting of fibrosis as mTORC2 activity has been implicated in the non-canonical signaling of TGF- $\beta$ (53) and lung fibrosis (54). Ongoing studies in this model are focusing on the relative importance of TORC1 and TORC2 activity in the setting of radiation injury. 
Here, we have shown that systemic treatment with rapamycin is capable of preventing AECII senescence after irradiation and mitigating radiation lung fibrosis. Importantly, the protective effect on pneumocytes was a direct effect that could be observed in cultured pneumocytes, suggesting that the preventative effect was not merely due to a reduction in inflammation, oxidative stress, or other paracrine interactions. These data provide a therapeutic opportunity for patients for whom few effective therapies exist.

\section{Supplementary Material}

Refer to Web version on PubMed Central for supplementary material.

\section{Acknowledgments}

This research was supported in part by the Intramural Research Program of the National Institutes of Health, National Cancer Institute.

\section{References}

1. Fehrenbach H. Alveolar epithelial type II cell: defender of the alveolus revisited. Respiratory research. 2001; 2:33-46. [PubMed: 11686863]

2. Sisson TH, Mendez M, Choi K, Subbotina N, Courey A, Cunningham A, Dave A, Engelhardt JF, Liu X, White ES, Thannickal VJ, Moore BB, Christensen PJ, Simon RH. Targeted injury of type II alveolar epithelial cells induces pulmonary fibrosis. American journal of respiratory and critical care medicine. 2010; 181:254-263. [PubMed: 19850947]

3. Citrin DE, Shankavaram U, Horton JA, Shield W 3rd, Zhao S, Asano H, White A, Sowers A, Thetford A, Chung EJ. Role of type II pneumocyte senescence in radiation-induced lung fibrosis. Journal of the National Cancer Institute. 2013; 105:1474-1484. [PubMed: 24052614]

4. Laplante M, Sabatini DM. mTOR signaling in growth control and disease. Cell. 2012; 149:274-293. [PubMed: 22500797]

5. Faivre S, Kroemer G, Raymond E. Current development of mTOR inhibitors as anticancer agents. Nature reviews. Drug discovery. 2006; 5:671-688.

6. Johnson SC, Rabinovitch PS, Kaeberlein M. mTOR is a key modulator of ageing and age-related disease. Nature. 2013; 493:338-345. [PubMed: 23325216]

7. Harrison DE, Strong R, Sharp ZD, Nelson JF, Astle CM, Flurkey K, Nadon NL, Wilkinson JE, Frenkel K, Carter CS, Pahor M, Javors MA, Fernandez E, Miller RA. Rapamycin fed late in life extends lifespan in genetically heterogeneous mice. Nature. 2009; 460:392-395. [PubMed: 19587680]

8. Iglesias-Bartolome R, Patel V, Cotrim A, Leelahavanichkul K, Molinolo AA, Mitchell JB, Gutkind JS. mTOR inhibition prevents epithelial stem cell senescence and protects from radiation-induced mucositis. Cell stem cell. 2012; 11:401-414. [PubMed: 22958932]

9. Panganiban RA, Day RM. Inhibition of IGF-1R prevents ionizing radiation-induced primary endothelial cell senescence. PloS one. 2013; 8:e78589. [PubMed: 24205274]

10. Laberge RM, Sun Y, Orjalo AV, Patil CK, Freund A, Zhou L, Curran SC, Davalos AR, WilsonEdell KA, Liu S, Limbad C, Demaria M, Li P, Hubbard GB, Ikeno Y, Javors M, Desprez PY, Benz CC, Kapahi P, Nelson PS, Campisi J. MTOR regulates the pro-tumorigenic senescence-associated secretory phenotype by promoting IL1A translation. Nature cell biology. 2015; 17:1049-1061. [PubMed: 26147250]

11. Neff F, Flores-Dominguez D, Ryan DP, Horsch M, Schroder S, Adler T, Afonso LC, AguilarPimentel JA, Becker L, Garrett L, Hans W, Hettich MM, Holtmeier R, Holter SM, Moreth K, Prehn C, Puk O, Racz I, Rathkolb B, Rozman J, Naton B, Ordemann R, Adamski J, Beckers J, Bekeredjian R, Busch DH, Ehninger G, Graw J, Hofler H, Klingenspor M, Klopstock T, Ollert M, Stypmann J, Wolf E, Wurst W, Zimmer A, Fuchs H, Gailus-Durner V, Hrabe de Angelis M, 
Ehninger D. Rapamycin extends murine lifespan but has limited effects on aging. The Journal of clinical investigation. 2013; 123:3272-3291. [PubMed: 23863708]

12. Yang H, Rudge DG, Koos JD, Vaidialingam B, Yang HJ, Pavletich NP. mTOR kinase structure, mechanism and regulation. Nature. 2013; 497:217-223. [PubMed: 23636326]

13. Rube CE, Uthe D, Wilfert F, Ludwig D, Yang K, Konig J, Palm J, Schuck A, Willich N, Remberger $\mathrm{K}$, Rube $\mathrm{C}$. The bronchiolar epithelium as a prominent source of pro-inflammatory cytokines after lung irradiation. International journal of radiation oncology, biology, physics. 2005; 61:14821492.

14. Chiang CS, Liu WC, Jung SM, Chen FH, Wu CR, McBride WH, Lee CC, Hong JH. Compartmental responses after thoracic irradiation of mice: strain differences. International journal of radiation oncology, biology, physics. 2005; 62:862-871.

15. Freund A, Orjalo AV, Desprez PY, Campisi J. Inflammatory networks during cellular senescence: causes and consequences. Trends in molecular medicine. 2010; 16:238-246. [PubMed: 20444648]

16. Ren JL, Pan JS, Lu YP, Sun P, Han J. Inflammatory signaling and cellular senescence. Cellular signalling. 2009; 21:378-383. [PubMed: 18992324]

17. Hallahan DE, Virudachalam S. Intercellular adhesion molecule 1 knockout abrogates radiation induced pulmonary inflammation. Proceedings of the National Academy of Sciences of the United States of America. 1997; 94:6432-6437. [PubMed: 9177235]

18. Weichhart T, Hengstschlager M, Linke M. Regulation of innate immune cell function by mTOR. Nat Rev Immunol. 2015; 15:599-614. [PubMed: 26403194]

19. Hara K, Maruki Y, Long X, Yoshino K, Oshiro N, Hidayat S, Tokunaga C, Avruch J, Yonezawa K. Raptor, a binding partner of target of rapamycin (TOR), mediates TOR action. Cell. 2002; 110:177-189. [PubMed: 12150926]

20. Pearce LR, Huang X, Boudeau J, Pawlowski R, Wullschleger S, Deak M, Ibrahim AF, Gourlay R, Magnuson MA, Alessi DR. Identification of Protor as a novel Rictor-binding component of mTOR complex-2. The Biochemical journal. 2007; 405:513-522. [PubMed: 17461779]

21. Wang L, Harris TE, Roth RA, Lawrence JC Jr. PRAS40 regulates mTORC1 kinase activity by functioning as a direct inhibitor of substrate binding. The Journal of biological chemistry. 2007; 282:20036-20044. [PubMed: 17510057]

22. Sengupta S, Peterson TR, Laplante M, Oh S, Sabatini DM. mTORC1 controls fasting-induced ketogenesis and its modulation by ageing. Nature. 2010; 468:1100-1104. [PubMed: 21179166]

23. Blagosklonny MV. Cell cycle arrest is not yet senescence, which is not just cell cycle arrest: terminology for TOR-driven aging. Aging. 2012; 4:159-165. [PubMed: 22394614]

24. Choo AY, Yoon SO, Kim SG, Roux PP, Blenis J. Rapamycin differentially inhibits S6Ks and 4EBP1 to mediate cell-type-specific repression of mRNA translation. Proceedings of the National Academy of Sciences of the United States of America. 2008; 105:17414-17419. [PubMed: 18955708]

25. Feldman ME, Apsel B, Uotila A, Loewith R, Knight ZA, Ruggero D, Shokat KM. Active-site inhibitors of mTOR target rapamycin-resistant outputs of mTORC1 and mTORC2. PLoS Biol. 2009; 7:e38. [PubMed: 19209957]

26. Thoreen CC, Kang SA, Chang JW, Liu Q, Zhang J, Gao Y, Reichling LJ, Sim T, Sabatini DM, Gray NS. An ATP-competitive mammalian target of rapamycin inhibitor reveals rapamycinresistant functions of mTORC1. The Journal of biological chemistry. 2009; 284:8023-8032. [PubMed: 19150980]

27. Demidenko ZN, Zubova SG, Bukreeva EI, Pospelov VA, Pospelova TV, Blagosklonny MV. Rapamycin decelerates cellular senescence. Cell cycle. 2009; 8:1888-1895. [PubMed: 19471117]

28. Kolesnichenko M, Hong L, Liao R, Vogt PK, Sun P. Attenuation of TORC1 signaling delays replicative and oncogenic RAS-induced senescence. Cell cycle. 2012; 11:2391-2401. [PubMed: 22627671]

29. Pospelova TV, Leontieva OV, Bykova TV, Zubova SG, Pospelov VA, Blagosklonny MV. Suppression of replicative senescence by rapamycin in rodent embryonic cells. Cell cycle. 2012; 11:2402-2407. [PubMed: 22672902]

30. Yentrapalli R, Azimzadeh O, Sriharshan A, Malinowsky K, Merl J, Wojcik A, Harms-Ringdahl M, Atkinson MJ, Becker KF, Haghdoost S, Tapio S. The PI3K/Akt/mTOR pathway is implicated in 
the premature senescence of primary human endothelial cells exposed to chronic radiation. PloS one. 2013; 8:e70024. [PubMed: 23936371]

31. Luo Y, Li L, Zou P, Wang J, Shao L, Zhou D, Liu L. Rapamycin enhances long-term hematopoietic reconstitution of ex vivo expanded mouse hematopoietic stem cells by inhibiting senescence. Transplantation. 2014; 97:20-29. [PubMed: 24092377]

32. Rube CE, Uthe D, Schmid KW, Richter KD, Wessel J, Schuck A, Willich N, Rube C. Dosedependent induction of transforming growth factor beta (TGF-beta) in the lung tissue of fibrosisprone mice after thoracic irradiation. International journal of radiation oncology, biology, physics. 2000; 47:1033-1042.

33. Anscher MS, Thrasher B, Zgonjanin L, Rabbani ZN, Corbley MJ, Fu K, Sun L, Lee WC, Ling LE, Vujaskovic Z. Small molecular inhibitor of transforming growth factor-beta protects against development of radiation-induced lung injury. International journal of radiation oncology, biology, physics. 2008; 71:829-837.

34. Liu W, Ding I, Chen K, Olschowka J, Xu J, Hu D, Morrow GR, Okunieff P. Interleukin 1beta (IL1B) signaling is a critical component of radiation-induced skin fibrosis. Radiation research. 2006; 165:181-191. [PubMed: 16435917]

35. Saito-Fujita T, Iwakawa M, Nakamura E, Nakawatari M, Fujita H, Moritake T, Imai T. Attenuated lung fibrosis in interleukin 6 knock-out mice after C-ion irradiation to lung. Journal of radiation research. 2011; 52:270-277. [PubMed: 21628844]

36. Coppe JP, Desprez PY, Krtolica A, Campisi J. The senescence-associated secretory phenotype: the dark side of tumor suppression. Annual review of pathology. 2010; 5:99-118.

37. Zhang M, Qian J, Xing X, Kong FM, Zhao L, Chen M, Lawrence TS. Inhibition of the tumor necrosis factor-alpha pathway is radioprotective for the lung. Clinical cancer research : an official journal of the American Association for Cancer Research. 2008; 14:1868-1876. [PubMed: 18347190]

38. Rider P, Carmi Y, Guttman O, Braiman A, Cohen I, Voronov E, White MR, Dinarello CA, Apte RN. IL-1alpha and IL-1beta recruit different myeloid cells and promote different stages of sterile inflammation. Journal of immunology. 2011; 187:4835-4843.

39. Brach MA, Gruss HJ, Kaisho T, Asano Y, Hirano T, Herrmann F. Ionizing radiation induces expression of interleukin 6 by human fibroblasts involving activation of nuclear factor-kappa B. The Journal of biological chemistry. 1993; 268:8466-8472. [PubMed: 8473290]

40. Mukhopadhyay S, Hoidal JR, Mukherjee TK. Role of TNFalpha in pulmonary pathophysiology. Respiratory research. 2006; 7:125. [PubMed: 17034639]

41. Nassim R, Mansure JJ, Chevalier S, Cury F, Kassouf W. Combining mTOR inhibition with radiation improves antitumor activity in bladder cancer cells in vitro and in vivo: a novel strategy for treatment. PloS one. 2013; 8:e65257. [PubMed: 23799002]

42. Ushijima H, Suzuki Y, Oike T, Komachi M, Yoshimoto Y, Ando K, Okonogi N, Sato H, Noda SE, Saito J, Nakano T. Radio-sensitization effect of an mTOR inhibitor, temsirolimus, on lung adenocarcinoma A549 cells under normoxic and hypoxic conditions. Journal of radiation research. 2015; 56:663-668. [PubMed: 25887043]

43. Hayman TJ, Wahba A, Rath BH, Bae H, Kramp T, Shankavaram UT, Camphausen K, Tofilon PJ. The ATP-competitive mTOR inhibitor INK128 enhances in vitro and in vivo radiosensitivity of pancreatic carcinoma cells. Clinical cancer research : an official journal of the American Association for Cancer Research. 2014; 20:110-119. [PubMed: 24198241]

44. Nam HY, Han MW, Chang HW, Lee YS, Lee M, Lee HJ, Lee BW, Lee HJ, Lee KE, Jung MK, Jeon H, Choi SH, Park NH, Kim SY, Kim SW. Radioresistant cancer cells can be conditioned to enter senescence by mTOR inhibition. Cancer research. 2013; 73:4267-4277. [PubMed: 23722550]

45. Dai ZJ, Gao J, Kang HF, Ma YG, Ma XB, Lu WF, Lin S, Ma HB, Wang XJ, Wu WY. Targeted inhibition of mammalian target of rapamycin (mTOR) enhances radiosensitivity in pancreatic carcinoma cells. Drug design, development and therapy. 2013; 7:149-159.

46. Kim EJ, Jeong JH, Bae S, Kang S, Kim CH, Lim YB. mTOR inhibitors radiosensitize PTENdeficient non-small-cell lung cancer cells harboring an EGFR activating mutation by inducing autophagy. Journal of cellular biochemistry. 2013; 114:1248-1256. [PubMed: 23592446] 
47. Kaplan B, Qazi Y, Wellen JR. Strategies for the management of adverse events associated with mTOR inhibitors. Transplant Rev (Orlando). 2014; 28:126-133. [PubMed: 24685370]

48. McCormack FX, Inoue Y, Moss J, Singer LG, Strange C, Nakata K, Barker AF, Chapman JT, Brantly ML, Stocks JM, Brown KK, Lynch JP 3rd, Goldberg HJ, Young LR, Kinder BW, Downey GP, Sullivan EJ, Colby TV, McKay RT, Cohen MM, Korbee L, Taveira-DaSilva AM, Lee HS, Krischer JP, Trapnell BC. National Institutes of Health Rare Lung Diseases, C., and Group, MT. Efficacy and safety of sirolimus in lymphangioleiomyomatosis. N Engl J Med. 2011; 364:15951606. [PubMed: 21410393]

49. Kondratov RV, Kondratova AA. Rapamycin in preventive (very low) doses. Aging. 2014; 6:158159. [PubMed: 24670390]

50. Benjamin D, Colombi M, Moroni C, Hall MN. Rapamycin passes the torch: a new generation of mTOR inhibitors. Nature reviews. Drug discovery. 2011; 10:868-880. [PubMed: 22037041]

51. Gravina GL, Marampon F, Sherris D, Vittorini F, Di Cesare E, Tombolini V, Lenzi A, Jannini EA, Festuccia C. Torc1/Torc2 inhibitor, Palomid 529, enhances radiation response modulating CRM1mediated survivin function and delaying DNA repair in prostate cancer models. The Prostate. 2014; 74:852-868. [PubMed: 24715588]

52. Kahn J, Hayman TJ, Jamal M, Rath BH, Kramp T, Camphausen K, Tofilon PJ. The mTORC1/ mTORC2 inhibitor AZD2014 enhances the radiosensitivity of glioblastoma stem-like cells. Neurooncology. 2014; 16:29-37. [PubMed: 24311635]

53. Yu JS, Ramasamy TS, Murphy N, Holt MK, Czapiewski R, Wei SK, Cui W. PI3K/mTORC2 regulates TGF-beta/Activin signalling by modulating Smad2/3 activity via linker phosphorylation. Nature communications. 2015; 6:7212.

54. Chang W, Wei K, Ho L, Berry GJ, Jacobs SS, Chang CH, Rosen GD. A critical role for the mTORC2 pathway in lung fibrosis. PloS one. 2014; 9:e106155. [PubMed: 25162417] 


\section{SUMMARY}

Rapamycin and inhibitors of mTOR signaling have been shown to sensitize tumor cells to irradiation. Inhibitors of mTOR signaling have also been shown to prevent senescence, a process implicated in pneumocyte depletion and lung injury. Thus, mTOR inhibition may simultaneously provide a means to sensitize tumor to irradiation and protect lung from radiation injury. The clinical development of agents inhibiting mTOR or mTORC1/2 provides a unique opportunity for clinical translation. 

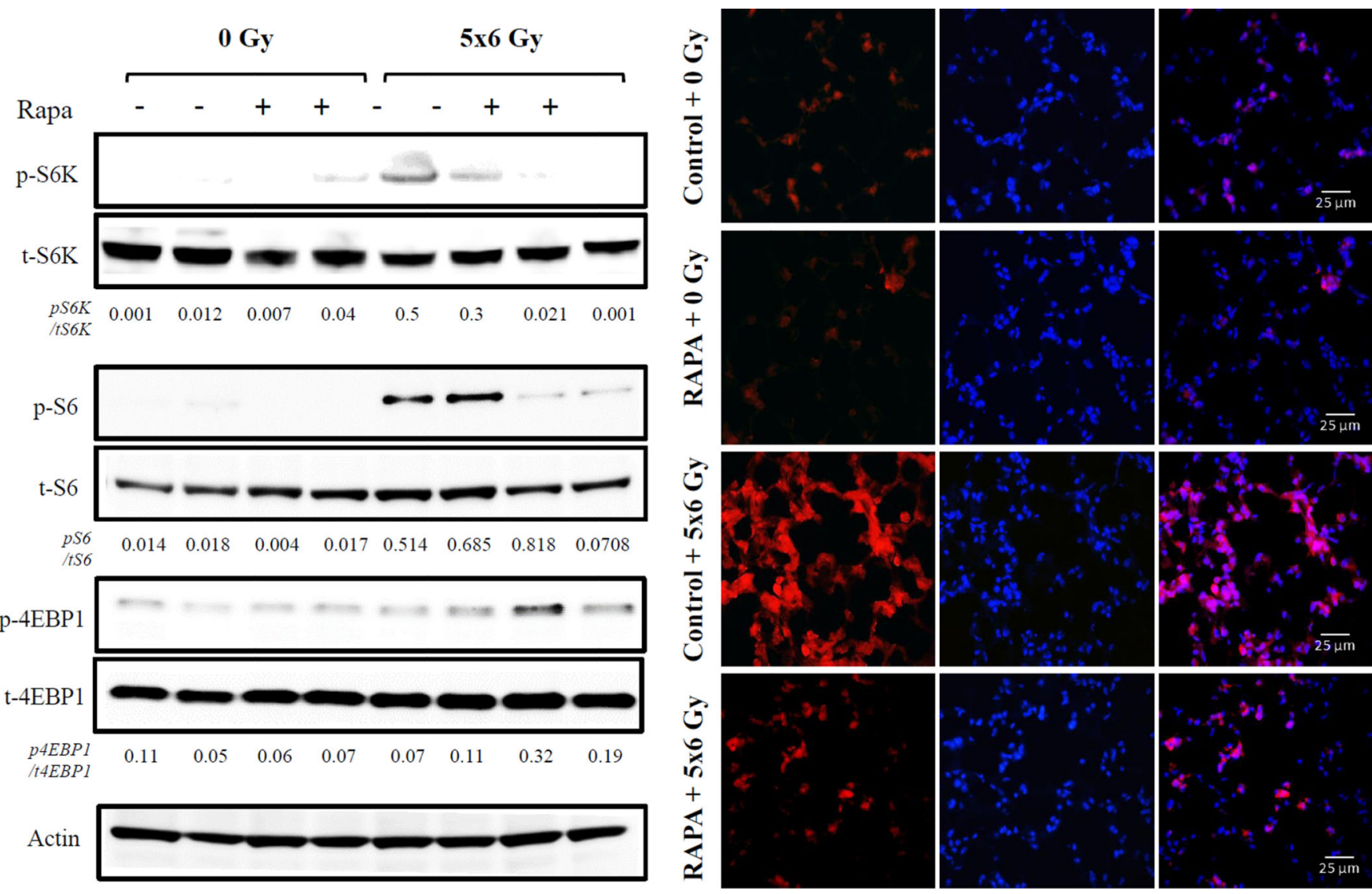

A

$\mathrm{B}$

p-S6

DAPI

Merged

Figure 1. Rapamycin inhibits mTOR signaling in irradiated lung

Lung tissue from $\mathrm{C} 57 \mathrm{BL} / 6 \mathrm{NCr}$ mice treated with $5 \times 6 \mathrm{~Gy}$ of thoracic IR and control or rapamycin formulated diet was collected at 16 weeks after IR ( $n=3$ per condition) and evaluated by western blotting for phosphorylated/total S6K, 4EBP1, and S6, with actin used as a loading control. The density of each band relative to the indicated loading control is noted below each band. (A). Sections of lung tissue from 16 weeks after IR were evaluated by immunohistochemistry for expression of phosphorylated S6 (red fluorescence) with DAPI (blue) as a nuclear counterstain (B) 

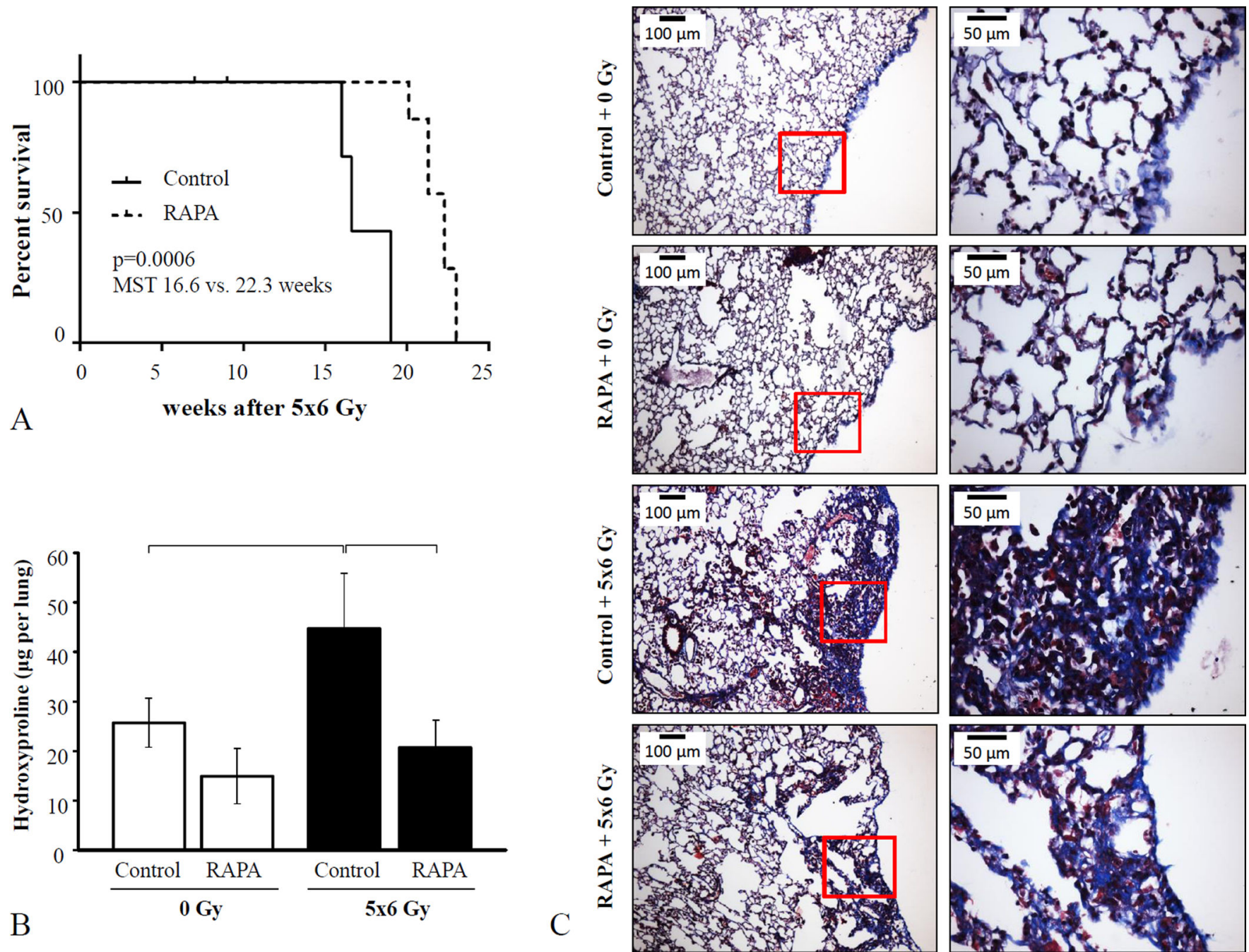

Figure 2. Effects of rapamycin on RIPF

C57BL/6NCr Mice were exposed to $5 \times 6$ Gy of thoracic IR and treated with rapamycin or control diet. A) Kaplan-Meier survival analysis demonstrated that administration of rapamycin extended survival compared to mice receiving control diet after IR. B) Lung tissue collected at 16 weeks after IR was analyzed for hydroxyproline content $(n=3$ mice per condition). C) Masson trichrome staining of lung tissue at 16 weeks after IR. Collagen: blue, nuclei: purple, cytoplasm/epithelia: pink. Columns: mean, error bars: SD, brackets: $\mathrm{p}<0.05$ by ANOVA. 

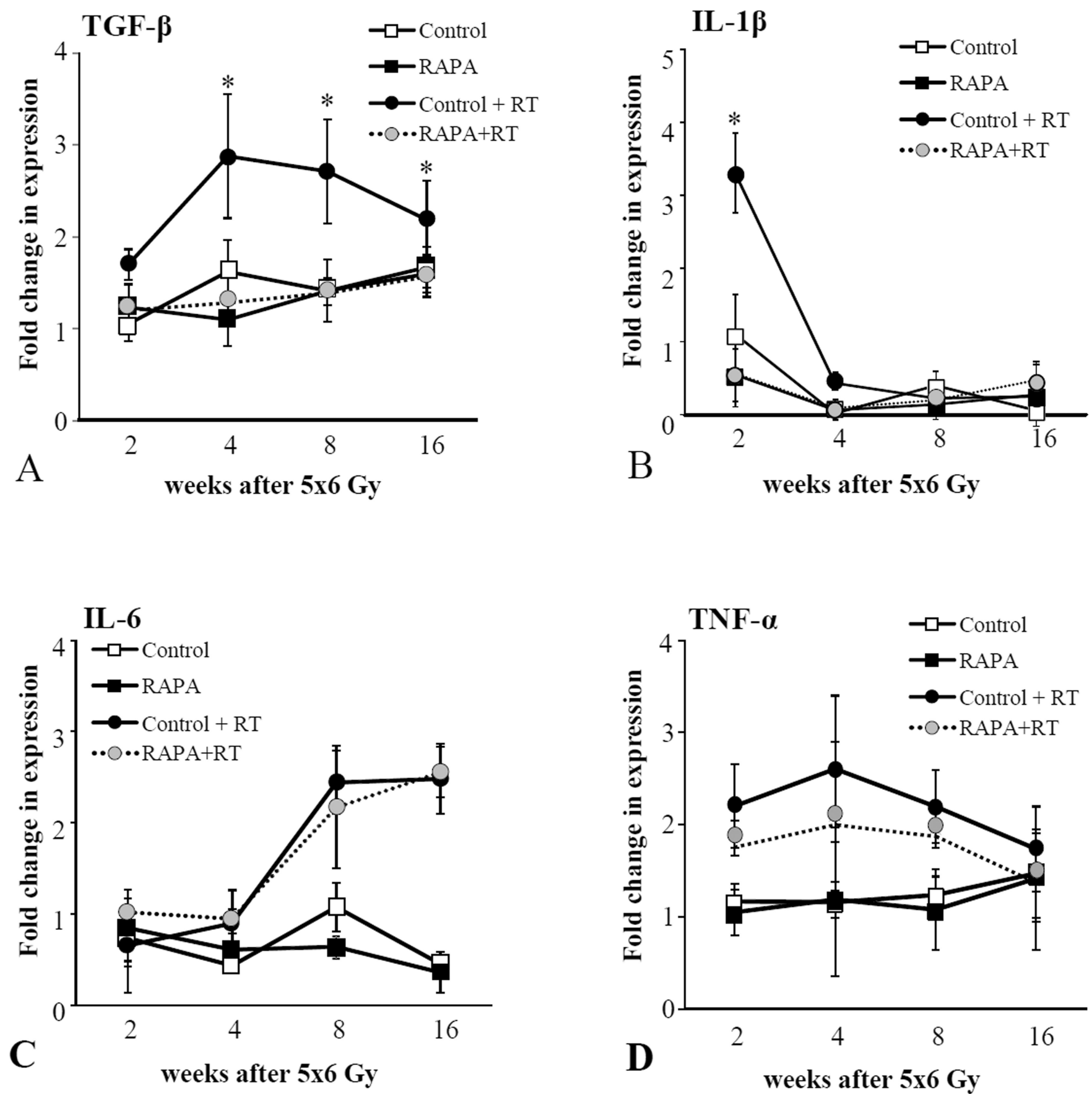

Figure 3. Effects of rapamycin on cytokine expression in irradiated lungs Lung tissue from C57BL/6NCr mice treated with $5 \times 6$ Gy of thoracic IR and control or rapamycin formulated diet was collected at 2, 4, 8 and 16 weeks after IR ( $n=3$ per condition). RNA was isolated and quantitative real time PCR was performed to determine the expression of TGF- $\beta$ (A), IL-1 $\beta$ (B), IL-6 (C), and TNF- $\alpha$ (D) normalized to HPRT1 as an internal control. Bars: mean. Error bars: standard error. ${ }^{*} \mathrm{p}<0.05$ for the comparison of RAPA + RT to control + RT at the same time point by ANOVA. 


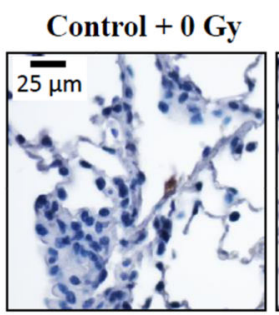

A
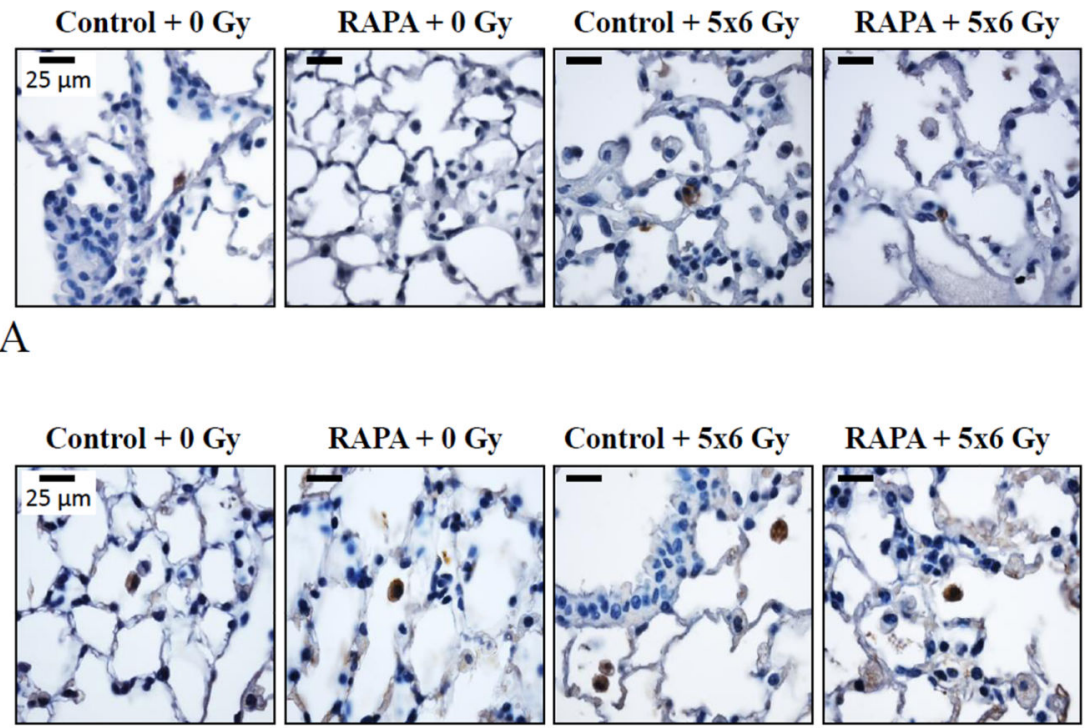

$\mathrm{B}$

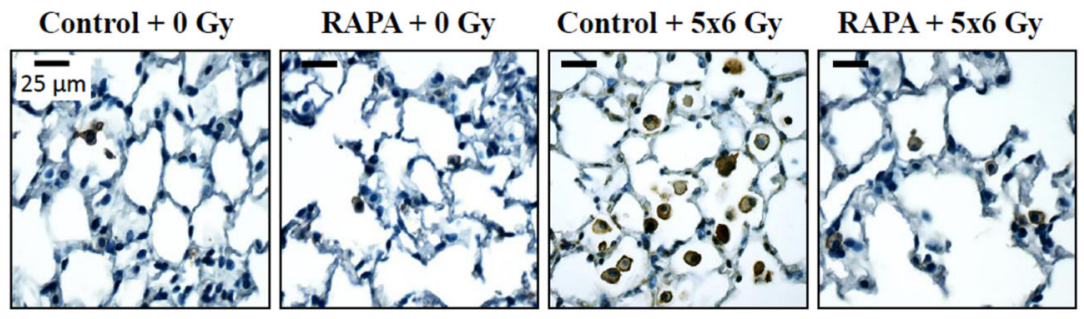

C
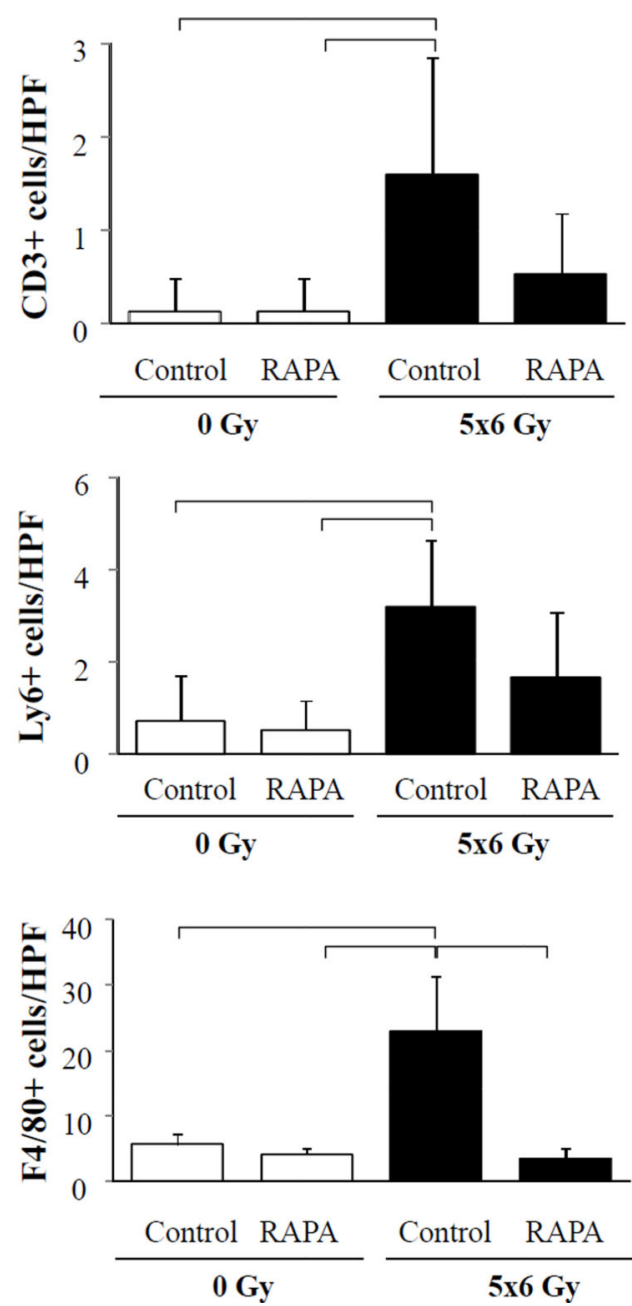

Figure 4. Rapamycin reduces macrophage accumulation in irradiated lungs

Lung tissue from C57BL/6NCr mice treated with $5 \times 6$ Gy of thoracic IR and control or rapamycin formulated diet was collected at 16 weeks after IR and processed for immunohistochemistry ( $\mathrm{n}=3$ per condition). The number of T-cells (A), neutrophils (B), and macrophages $(\mathrm{C})$ detected per high power field (HPF, 63X) were compared between each treatment. DAB (brown) was used as the chromogen in each example with hematoxylin as the counterstain (left panels). Columns: mean, error bars: SD, brackets: $\mathrm{p}<0.05$ by ANOVA. 

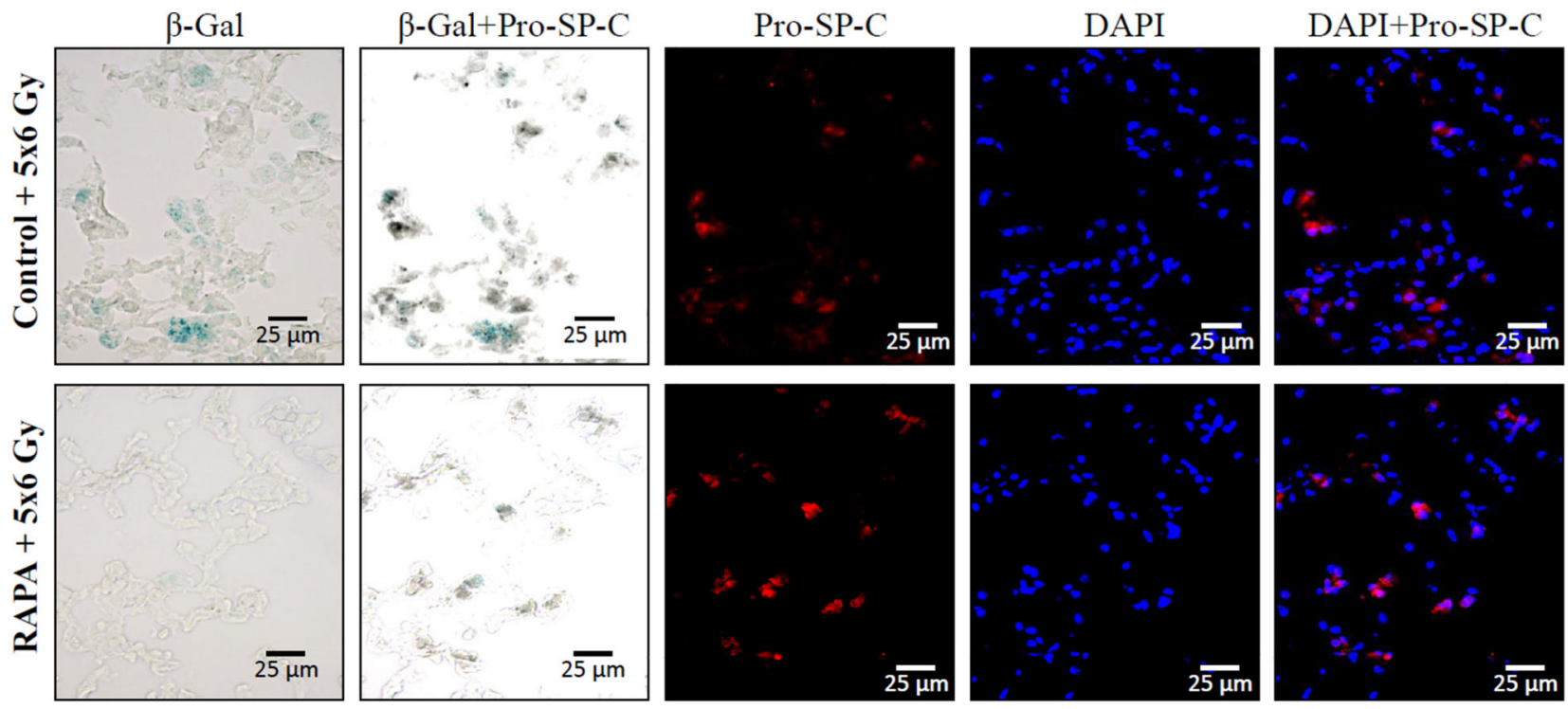

A
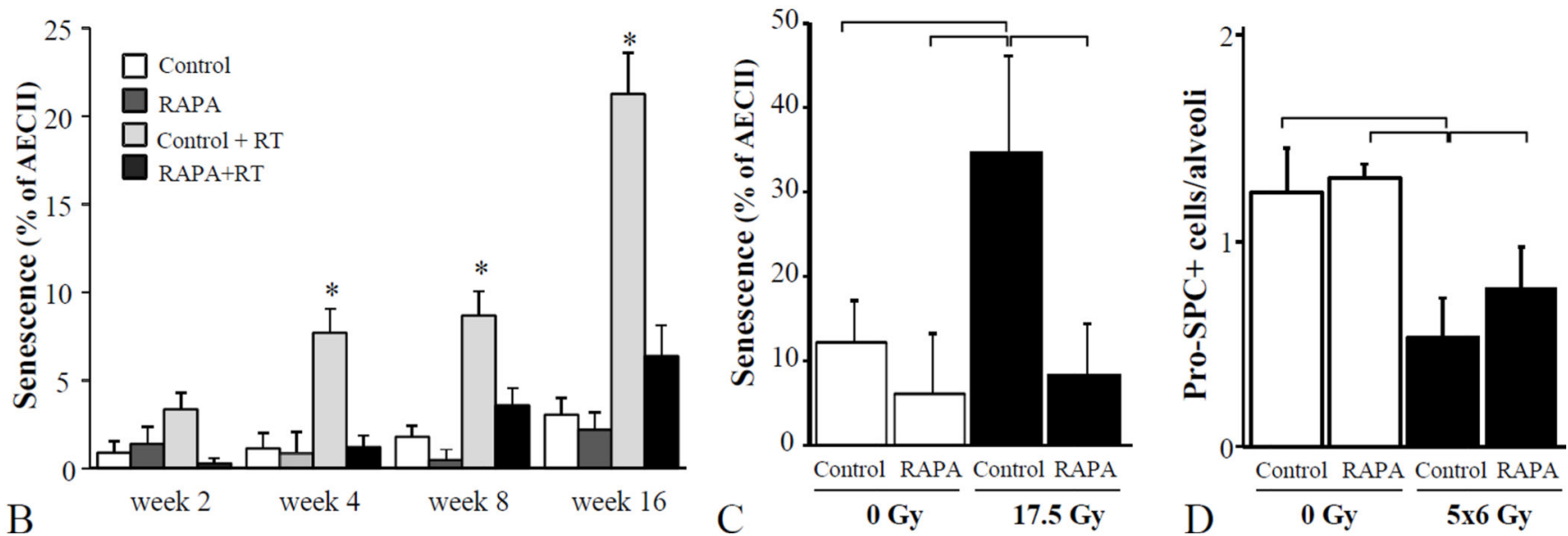

Figure 5. Rapamycin reduces AECII senescence after irradiation

Lung tissue from C57BL/6NCr mice treated with $5 \times 6$ Gy of thoracic IR and control or rapamycin formulated diet was collected after IR ( $n=3$ per condition). The percentage of type II pneumocyte (AECII) cells (stained by Pro-SP-C) staining for $\beta$-Gal activity at $2,4,8$, and 16 weeks after IR was scored. A) Representative images at week 16 after IR, B) Percentage of AECII co-stained with Pro-SP-C at 16 weeks after IR. C) Primary pneumocyte cultures were treated with rapamycin $(0,50 \mathrm{ng} / \mathrm{ml})$ or vehicle for one hour prior to IR (17.5 Gy). Cells were fixed after 3 days and co-stained for $\beta$-Gal and pro-surfactant $C$ (pro-SPC). The percent of pro SP-C stained cells that stained for $\beta$-Gal were scored. D) The number of AECII per alveolus was scored in mouse lung at 16 weeks after IR. Bars: mean; error bars: standard error; ${ }^{*} p<0.05$ for the comparison to rapamycin $+5 \times 6$ Gy treatment at the same time point by ANOVA. 